\title{
The Research on Structural Dimensions of Institutional Regulation of Place Branding
}

\author{
Weihong ZHAO, Ganfeng YU \\ Jiangxi Normal University, Nan Chang, China \\ zwh4005@sina.com; yugf123@126.com
}

\begin{abstract}
The aims of this article is to establish a dimensional model of institutional regulation of place branding, to help the region to establish a impeccable regulatory system in the branding process. Through literature review, this paper puts forward the conceptual model of institutional regulation of place branding. This paper argues that institutional regulation of place branding including political regulation, economic regulation and social regulation and environmental regulation. the model for place brand construction has a certain guiding significance to avoid opportunistic behavior in the process of place branding.
\end{abstract}

KEYWORD: institutional regulation; place branding; opportunistic behavior

\section{INTRODUCTION}

Competition between region and region become more and more intense, especially in this moment that the tendency of globalized economy is developing. As a driving force for regional marketing, place branding has been proven is the focus of marketing in regional marketing practice of many parts of the region. Rainisto (2010) also told that place branding will be the fastest growing field in the area of place marketing in the next decade.

Some cities and regions created a brand recognition effect that different from other cities and regions successfully by place branding. For example, France win a "Wine Country" title because of its unique geographical environment, and strictly control the wine production process, and ultimately produce high-quality wines. However, not all place branding is successful, New Zealand milk powder was famous for high yield and high quality ,but after been reveled contain botulinum, the image in the consumer's mind plummeted, and turn to buy the milk powder of other countries. The fountainhead of the event was part of the New Zealand dairy giant---Fonterra was detected to contain botox, finally spread to damage collective image of New Zealand dairy industry. There are many cases like this, through the analysis of above, we find that the lack of perfect institution will bring a lot of problems in the process of place branding, and finally damage the interests of the whole place brand.

Based on the above analysis, place branding is an opportunity for a area, however, if lack of perfect system to regulate the behavior of stakeholders in the process of place branding, the place brand will not get good development .Then the question has coming, what is the institutional regulation of place branding? And what is the dimensions of institutional regulation? All of these will be studied in the paper.

\section{INSTITUTIONAL REGULATION}

Institutional regulation is through a series of formal rules, laws and the informal industry standards to influence the behavior of the actors. DiMaggio and Powell (1983) thought institutional regulation is part of the new institutionalism, and point out that the regulation is consists of formal and informal pressure, but does not accurately describe the definition. Scott (2001) consider that the regulation is the key element of institution by summarizing the results of other researchers, also point out that regulation would influence the behavior in the future by establishing rules and supervise others follow the rules, and if necessary, can also implement rewards and punishments. Many domestic and foreign scholar from different disciplines analyzed the regulation from different perspective, all mentioned the core content of the institutional regulation---binding. For example, economic perspective: Liu (2007) consider that regulation is an administrative mean to intervene the market to ensure the optimal deployment of resource and equitable supply of service, including the price, the market access, rate 
of return, etc. Spulber (1999) consider that regulation is formulated by the administrative agency and direct intervene allocation of market or indirectly change supply and demand decisions of enterprise and consumer general rules or special behavior. Plolitics-based perspective: Meier (1985) define regulation is any attempt of government control of behavior of citizens, nation, or quasigovernment organization. Garsten and Jacobsson (2011) thought regulation is a kind of soft power, including control and transform the microscopic forms, the conditions of constraints and restrictions apply to political choice. These is also the definition of regulation in the law perspective, because this article is mainly involved in economics and political science, therefore, not consider the perspective.

According to the concept of the regulation above, this paper argues that institutional regulation of place branding refers to region control stakeholders of place brand by establish a series of formal and informal rules and system, finally realize place branding.

\section{THE DIMENSIONS OF INSTITUTIONAL REGULATION OF PLACE BRANDING}

\subsection{The dimensions of institutional regulation}

Thought about the dimensions of institutional regulation, DiMaggio and powell (1983) told that regulatory pressure to be seen as a kind of power to persuade or invite, in turn, enable organization to join the conspiracy, and the change of organizational behavior is a direct response to the pressure, although it is possible that response is a kind of courtesy, but does not mean that it doesn't matter. At the same time, they also pointed out that the isomorphism of regulation is not only including a courtesy .Scott (2001) pointed out the core element of regulation contain mandatory violence, rewards and punishments and expedient strategy reaction, but they also be water down because of the existence of rules, these rules include formal laws and regulations, institution and informal mores, customs. Many theorists emphasize the importance of cultural symbols system to realize the ordering of social life, and it not only have a purpose, also emotional (D.Andrade, 1984; Thoits, 1989). Almost any kind of stimulation, can cause some kind of emotional reaction, the consequences of emotional response is different degree of approval or rejection. Ma (2012) mentioned regulation including command-control regulation, incentive regulation and voluntary regulation with study for environment regulation. Also some scholars will be divided into social regulation, economic regulation and cultural regulation (Ma Jian, 2012). In view of there are lots of researchers who study the dimensions of institutional regulation, the author summarizes the structure and properties of institutional regulation (table 1).

Although the literature about the institutional regulation has not form a unified view, we also can find common from the table. First is the dimension of institutional regulation change from multidimensional structure to multidimensional structure for the second order; The second is the first-order dimension of institutional regulation by original mandatory, rewards and punishments and ambiguity of developed some new dimensions (relational, affective);

Table 1 the dimension of institutional regulation

\begin{tabular}{|c|c|c|c|}
\hline $\begin{array}{l}\text { Dimensions of } \\
\text { regulation }\end{array}$ & Attribute & Under attribute & Researcher \\
\hline \multirow{3}{*}{$\begin{array}{l}\text { Political } \\
\text { regulation }\end{array}$} & Coerciveness & & \multirow{3}{*}{$\begin{array}{l}\text { Cetin \& Eryigit } \\
(2013) ; \operatorname{Scott}(2001)\end{array}$} \\
\hline & Motivative & & \\
\hline & Expedient & & \\
\hline \multirow{2}{*}{$\begin{array}{l}\text { Economic } \\
\text { regualtion }\end{array}$} & Industry regulation & Price, access, quality, quantity & \multirow{2}{*}{$\begin{array}{l}\text { Haakana\& Lassila; } \\
\text { Qu (2003) }\end{array}$} \\
\hline & Market regulation & Monopoly, unfair trade & \\
\hline \multirow{3}{*}{$\begin{array}{l}\text { Social } \\
\text { regulation }\end{array}$} & Safety regulation & Health and hygiene, consumer protection, life safety & Qu (2003) \\
\hline & Emotional regulation & Identity, sense of shame, pride & Scoot (2008) \\
\hline & Relational regulation & $\begin{array}{l}\text { Integration degree, cooperation degree, group location, } \\
\text { organizational relationships }\end{array}$ & $\begin{array}{l}\text { Lakey \& Orehek } \\
(2011)\end{array}$ \\
\hline \multirow{3}{*}{$\begin{array}{l}\text { Environmental } \\
\text { regulation }\end{array}$} & Command-control regulation & Laws, rules, policies & Hahn R W (1990) \\
\hline & Incentive regulation & $\begin{array}{l}\text { Pollution charge system, subsidies, tradable permits } \\
\text { and deposit a refund policy }\end{array}$ & Ma (2012) \\
\hline & voluntary regulation & $\begin{array}{l}\text { Information disclosure, environmental certification, } \\
\text { environmental signs, environmental hearing system, } \\
\text { voluntary agreement, and clean production }\end{array}$ & Blackman A (2010) \\
\hline
\end{tabular}


Third, with the development of regulation theory research, originally belonging to the political regulation of social regulation and economic regulation has become the second independent status dimension, originally belong to the same social regulation of environmental regulation has developed into a second status dimension.

\subsection{The dimensions of institutional regulation of place branding}

This study for institutional regulation of place branding is based on the regulatory dimension of the three pillars of institutional theory, thus excluding the dimension of cultural regulation. Government, corporate, guilds and other stakeholders and the public will join in the process of place branding, these individuals and groups supervise, coordinate and manage each other to achieve place branding. And these supervision, coordination and management need a sound institutional system to ensure complete. From the table 1, we can find that economic regulation and social regulation are the two most important dimensions, because whether it is at the place brands, or in other industries, price regulation, quality regulation, quantity regulation and monopoly regulation, unfair trade regulation in the industry regulation and market regulation include in the economic regulation are both very concerned content to businesses, consumers and governments. Also health, life safety, identity and extent of cooperation include in the social regulation get the same attention. Institutional regulation of place branding is carried out under the guidance of the government, therefore, political regulation is an important complement to the social regulation and economic regulation, and support the realization of the two previous regulations. There are many scholars believe that environmental regulation is an very important dimension of institutional regulation (Hahn R W,1990; Ma,2012 ; Blackman A, etc,2010). In fact, in the place branding process, the regional environment is an important part of the region, so the system must include regulation of regional environmental regulations.

To sum up, this paper argues that institutional regulation of place branding including political regulation, economic regulation and social regulation and environmental regulation. Among them, the political regulation refers to by establishing rules, supervision and others follow the rules, and if necessary, and the implementation of rewards and punishments to influence future behavior; Economical regulation refers to the policies and measures, through a certain build a similar competition mechanism of incentive mechanism to guide the monopoly of economic decisions or take mandatory measures, the natural monopoly industry market access, price, yield, quality, etc, to make clear rules; Social regulation refers to ensure the health and hygiene, ensure safety, prevent disasters, disease and work to protect consumers, traffic safety, fire protection, gun ban), prevent pollution and protect the environment, to ensure the education culture and welfare.

\section{CONCLUSION}

Through literature review, this paper puts forward the conceptual model of institutional regulation of place branding, the model for place brand construction has a certain guiding significance to avoid opportunistic behavior in the process of place branding. Regulatory body of place brand can regulate the stakeholders from the four aspects of economic, social, political and environment. However, this research also has limitation. This research is mainly built on the basis of literature review, then lack of empirical data inspection. Therefore, the focus of the next research is based on literature review and interview, following is scale development, research design, data collection and analysis, using an empirical analysis of the scientific method to test adequacy of the model.

\section{ACKNOWLEDGMENTS}

We are grateful for the financial support of the 2009 Soft Science Research Project (2009DR04400) offered by Jiangxi Provincial Department of Science and Technology, and the 2013 Social Science Planning Project (13GL09) offered by Jiangxi Provincial Association of Social Science.

\section{REFERENCES}

[1] Di Maggio P J, Walter W P, the Iron Cage Revisited: Institutional Isomorphism and Collective Rationality in Organizational Fields. American Sociological Review, $1983,48$.

[2] Oliver, C. Strategic Responses to Institutional Processes. Academy of Management Review, 1991, 16.

[3] Scott W.R. The Adolescence of Institutional Theory. Administrative Science Quarterly, 1987, 32(4).

[4] Meier. Regulationg: Polities, Bureaucracy and Economics, New York: MartinsPress.p.8.

[5] Levasseur M, Richard L, Gauvin L and Raymond E. Inventory and analysis of definitions of social participation found in the aging literature: proposed taxonomy of social activities. Social Sci Med 2010; 71(12): 2141-2149.

[6] Ma Fuping, Cha $\mathrm{Na}$.The influence of environmental regulation on technological innovation performance studies----institutional environment adjustment Research and Development Management, 2007 (3), Vol 27 (Sum No. 82): 19-23.

[7] Hahn R W. The political economy of environmental 
regulation: Towards a unifying framework. Public Choice, 1990, 65 (1), 21-47.

[8] Blackman A, Lahiri B, Pizer W, etal. Voluntary environmental regulation in developing countries: Mexico's clean industry program. Journal of Environmental Economics and Management,2010,60 (3): 182-192

[9] Tamer Cetin, Kadir Yasin Eryigit. The economic effects of government regulation: Evidence from the New York taxicab market. Transport Policy, 2013 (25): 169-177.

[10] Brian Lakey, Edward Orehek. Relational Regulation Theory: A New Approach to Explain the Link Between
Perceived Social Support and Mental Health. Psychological Review. 2011, Vol. 118, No. 3, 482-495.

[11] Tamer Çetin, Fuat Og uz. The effects of economic regulation in the Istanbul taxicab marketing. Economic Affairs, 2010 (10).

[12] John W. Meyer, Brain Rowan. Institusionalized Organizations: Formal Structure as Mythh and Ceremony. The American Journal of Sociology, 1977(83):340-363.

[13] Zenker, S. and Braun, E. (2010) Branding a city - A conceptual approach for place branding and place brand management. Paper presented at the 39th European Marketing Academy Conference; 1-4 June, Copenhagen, Denmark. 